\section{Withdrawal of low-dose prednisone in inactive SLE patients: Is there another alternative?}

I read with great interest, the recently published article in your journal titled 'Withdrawal of low-dose prednisone in systemic lupus erythematosus (SLE) patients with a clinically quiescent disease for more than 1 year: a randomised clinical trial' by Mathian et al. ${ }^{1}$ In this article, the authors conclude that the maintenance of long-term $5 \mathrm{mg}$ prednisone in SLE patients with inactive disease prevents relapses. In the recent update of European League Against Rheumatism (EULAR) recommendations for the management of SLE, ${ }^{2}$ the experts say that the 'treatment in SLE should aim at remission or low disease activity and prevention of flares in all organs, maintained with the lowest possible dose of glucocorticoids (GC)'. However, in my opinion, a daily dose of prednisone of $5 \mathrm{mg}$ might not be the lowest possible dose in patients with long-term inactive SLE, and there is an alternative strategy that consists of the progressive reduction of this dose, which has not been considered. I believe that the one-time withdrawal of $5 \mathrm{mg} /$ day is too abrupt and it could favour the appearance of flares. In contrast, many patients could benefit from a more gradual reduction. In this situation, the protocol of our unit is to decrease $1.25 \mathrm{mg}$ of prednisone every 2-3 months until it is suspended, or in case of relapse or flare, we maintain the previous effective dose for a longer time and then lower more slowly. The aim of this strategy is to decrease the accumulated dose of GC in order to prevent irreversible organ damage (Systemic Lupus International Collaborating Clinics/American College of Rheumatology Damage Index (SDI)) associated with its use. In this study, no significant differences in SDI and adverse effects were found between those who discontinued prednisone and those who maintained a daily dose of $5 \mathrm{mg}$ after 1 year of follow-up. However, this period may be too short, as some studies suggest that sustained low doses of GC may be associated with increased SDI. ${ }^{3}$ In summary, the alternative of a progressive dose reduction of prednisone in patients with long-term inactive SLE should be explored before deciding on indefinite maintenance of a daily dose of $5 \mathrm{mg} .{ }^{4}$

\section{José Mario Sabio}

Systemic Autoimmune Diseases Unit, Department of Internal Medicine, Hospital Virgen de las Nieves, Granada, Spain

Correspondence to Dr José Mario Sabio, Department of Internal Medicine, Hospital Virgen de las Nieves, 18014 Granada, Spain; jomasabio@gmail.com

Contributors JMS is the principal investigator.

Funding The authors have not declared a specific grant for this research from any funding agency in the public, commercial or not-for-profit sectors.

Competing interests None declared.

Patient and public involvement Patients and/or the public were not involved in the design, or conduct, or reporting, or dissemination plans of this research.

Patient consent for publication Not required.

Provenance and peer review Not commissioned; internally peer reviewed.

(c) Author(s) (or their employer(s)) 2020. No commercial re-use. See rights and permissions. Published by BMJ.

\section{Check for updates}

To cite Sabio JM. Ann Rheum Dis Epub ahead of print: [please include Day Month Year]. doi:10.1136/annrheumdis-2020-217575

Received 10 April 2020

Accepted 15 April 2020

Ann Rheum Dis 2020;0:1. doi:10.1136/annrheumdis-2020-217575

\section{ORCID iD}

José Mario Sabio http://orcid.org/0000-0003-4095-7379

\section{REFERENCES}

1 Mathian A, Pha M, Haroche J, et al. Withdrawal of low-dose prednisone in SLE patients with a clinically quiescent disease for more than 1 year: a randomised clinical trial. Ann Rheum Dis 2020;79:339-46.

2 Fanouriakis A, Kostopoulou M, Alunno A, et al. Update of the EULAR recommendations for the management of systemic lupus erythematosus. Ann Rheum Dis 2019;2019:736-45.

3 Zonana-Nacach A, Barr SG, Magder LS, et al. Damage in systemic lupus erythematosus and its association with corticosteroids. Arthritis Rheum 2000;43:1801-8.

4 Strehl C, Bijlsma JWJ, de Wit M, et al. Defining conditions where long-term glucocorticoid treatment has an acceptably low level of harm to facilitate implementation of existing recommendations: viewpoints from an EULAR Task force. Ann Rheum Dis 2016;75:952-7. 